\title{
Den 'rigtige' sex \\ - Moralsk orientering, seksualmoralisme og (hetero)normativitet i midt- og sen-00'ernes seksualdebat i Danmark
}

\begin{abstract}
"Statens opgave er ikke at være et ekko af hvilket som helst minoritetsseksuelt spørgsmål".1 Således udtalte daværende sundhedsminister Lars Løkke Rasmussen, da han i 2004 krævede ændringer i seksualundervisningsmaterialet Sexstar₹, fordi det ifølge ministeren bl.a. fremstillede analsex som "normalt" og forholdte sig "afslappet til gruppesex". Aret efter var forfatteren Jørgen Leth hovedperson i en sædelighedsfejde, der udløstes af hans beskrivelse af sit forhold til en ung haitisk kvinde i sin selvbiografi. Dagbladene kaldte Leth for "liderbasse" og "gammel gris", og han blev presset til at fratræde sin titel som konsul på Haiti og fyret fra sit mangeårige job som cykelløbskommentar på TV2. I foråret 2008 blev det socialdemokratiske folketingsmedlem Jeppe Kofod genstand for en mediepanik efter det kom frem, at han havde været i seng med en 15-årig pige (over den seksuelle lavalder) under et ungdomspolitisk stævne. Politikeren blev omgående fyret fra sine politiske ordførerposter.
\end{abstract}

En række seksualmoralske markeringer og sædelighedsfejder sætter i midt- og sen-00'erne ikke bare sindene i kog over særligt mænds intergenerationelle og tværetniske seksuelle tilbøjeligheder, men kan også registreres i artikulerede krav om lovgivne forbud og realpolitiske tiltag. Sexstarz-sagen fra 2004 var et eksempel på statscensur. I 2006 vedtog Københavns Kommune at forbyde ansatte at hjælpe handicappede med at tage kontakt til prostituerede, selv om det strider mod Socialministeriets anbefalinger fra 2001. Samme år vedtog kommunen et kodeks med en henstilling til kommunens politikere og ansatte om ikke at købe sex hos prostituerede - heller ikke i fritiden. Endelig er der det i de seneste år stadigt mere artikulerede krav om at kriminalisere køb af seksuelle tjenesteydelser fra en bred skare af aktører, foreninger og politiske partier, som SF (fra 2006), Enhedslisten (fra 2007) og Socialdemokraterne (fra 2009).

Eksemplerne peger på, at seksuelle lystfølelser og kropsudfoldelser er blevet genstand for særlig opmærksomhed og seksualmoralske markerin- 
ger $\mathrm{i}$ den danske offentlighed i midt og sen-00'erne. Det vækker selvsagt sociologisk undren og nysgerrighed efter at kaste et nærmere kritisk blik på, hvilke seksualmoralske holdninger og standpunkter der har været fremtrædende i medierne i de senere år, og om mere restriktive og invaderende seksualmoralske standpunkter, som de ovennævnte eksempler kan give anledning til at tro, har vundet større fremgang i medierne i perioden. Jeg har kastet et kritisk blik på de senere års seksualdebat i min undersøgelse af den danske avisdebat i perioden 2004 til 2006. Undersøgelsen består i en kvalitativ og kvantitativ tekstanalyse af avisdebatten om en række seksuelle fænomener, som analsex, gruppesex, 'gangbang', pornografi, seksualisering og pornoficering af det offentlige rum, samt prostitution. For at se forandringer og bevægelser, både kvalitativt og kvantitativt, over en tiårsperiode har jeg foretaget en tekstanalyse af de samme temaer i $1997 .^{2}$ Undersøgelsen udgør således, jævnfør den franske idéhistoriker og filosof Michel Foucaults arkæologiske udforskningsmetode, et bidrag til arkivet over de offentlige seksualmoralske diskurser inden for den seneste årti.

I denne artikel præsenteres - i kort form - hovedtrækkene af tekstanalysen med eksempler fra de forskellige debatter $i$ aviserne. Dernæst drøftes, hvordan det markante skift i debatklimaet og de seksualmoralske standpunkter i de trykte medier gennem det seneste årti, som min analyse viser, har bevæget seksualdebatten, der siden 1960'erne har været ikkeforbudsorienteret $\mathrm{og}$ baseret i højere grad på en personlig etik, 'tilbage' $i$ en moralsk forståelses- og analysehorisont præget af antagonistiske 'kampe' og seksualmoralistiske og (hetero)normative standpunkter vedrørende seksuelle og kropslige lyster. Min drøftelse bygger på Foucaults både filosofisk-analytiske og historisk-politiske skelnen mellem moral i kristnemoderne samfund og etik i den antikke verden. Jeg forfølger på den ene side Foucaults opfattelse af etikken som et slags historisk alternativ til den moderne forbudsmoral og som en moralsk horisont, der nok passer bedre til senmoderne sekulariserede samfundskontekster og svinger bedre med de værdier, som mennesker orienterer sig efter i dag. Afslutningsvis fremhæves på den anden side Foucaults etiske perspektiv som en frugtbar forståelseshorisont og analyseramme for seksualitetsfænomener, som pornografi og seksuelle lystformer. Her er vægten ikke lagt på aprioriske moralske domme om fænomener og adfærd, men bygger på en etisk sensibilitet og nysgerrighed over for kompleksiteten, ambivalenserne og perspektiverne i konkrete kontekster og menneskers egne oplevelser og følelser. Denne tilgang adskiller sig fra de rigide og ufravigelige hierarkisk- 
dikotomiske analysemodeller i forhold til køn, seksualitet, etnicitet etc., som er udbredt i megen feministisk seksualitetsforskning. I denne artikel gengiver jeg således ikke alle undersøgelsens resultater, men føjer nogle analytiske og teoretiske perspektiver til undersøgelsens resultater og den aktuelle danske seksualdebat. ${ }^{3}$

\section{Fra nysgerrighed til bekymring og frygt...}

Den kvantitative gennemgang af debatten om de forskellige seksualitetsfænomener fra 1997 og frem til 2006 viser en forholdsvis markant stigning i antallet af artikler efter årtusindskiftet; særlig signifikant er det stigende omfang af indlæg i medierne om pornografi, seksualisering, pornoficering og ikke mindst prostitution. Ser man på det kvalitative indhold i debatten, aftegner der sig også en markant forandring i de seksualmoralske standpunkter og i måden seksualitet diskuteres på i medierne fra 1997 til 2004-2006. I 1997-debatten syntes der at være en udbredt enighed - om end med få undtagelser fra hovedsageligt konservativ-kristne kredse - om en grundlæggende positiv, afslappet og nysgerrig tilgang til fx pornografi, gruppesex og analsex. Den udbredte opfattelse var, at kvinder og mænd kunne omgås hinanden - også hvis de kunne have lyst til at dyrke analsex sammen - på en passende måde for begge parter. Et anderledes billede viser sig i 2004-2006: Klangbunden i de fremherskende seksualmoralske markeringer og artikulationer var nu bekymring og frygt. Debatten var domineret af standpunkter, der udtrykte bekymring, angst og frygt vedrørende særligt kvinders og unges (og især unge kvinders) seksuelle adfærd. Store dele af debatten var også præget af et fordømmende og negativt syn på sex - "farligt", "unormalt", "afvigende", "skadeligt" og "usundt" var ikke sjældent de ord, der blev sat på analsex, gruppesex og pornografi i debatten.

Et udbredt standpunkt om analsex i debatten var, at det er kvindeundertrykkende, fordi kvinder enten bliver presset eller tvunget til analsex af en androcentrisk pornografi eller af fyrene, der har set porno. Det forhold, at analsex kropsgeografisk orienterer sig mod kvindens røvhul, konsoliderer ligeledes, hævdede feministen Jette Hansen, den generelle samfundsmæssige undertrykkelse af kvinder, fordi det understreger kvindekroppens historisk-kulturelle lavstatus og underordning $i$ forhold til mænd som forbundet med det "beskidte" - slim, blod - og nu altså også afføring. Lægen Vibeke Manniche hævdede, at: "De fleste kvinder unge kvinder 
giver senere udtryk for at analsex var en dårlig oplevelse", uden henvisninger til dokumentation for sin påstand. En anden læge udtalte, at hun havde 16-årige piger, der kom $\mathrm{i}$ hendes praksis for at få fjernet hæmorider, så de kunne dyrke analsex - "vaner" som ifølge lægen "tydeligvis stammer fra pornovideoer, og som jeg helt ærligt ikke tror en 16-årig pige bliver lykkelig af". Holdningerne i disse udsagn er, at kvinder og unge piger generelt ikke har lyst til eller kan blive inspireret til at dyrke analsex, uden at det er tvang fra enten pornografi eller mænd. Analsex går således ikke for at være en 'passende', 'rigtig' og 'normal' seksuel adfærd for unge kvinder; de må faktisk heller ikke rigtig dyrke analsex, fordi de bliver undertrykte og ofre - det gør dem ikke "lykkelige" (skal man blive lykkelig af analsex for at få lov til at dyrke det?). Den samme type argumentation og standpunkter dominerede også avisdebatten om gruppesex, 'gangbangs', pornografi, seksualisering og pornoficering af det offentlige rum i perioden 2004-2006.

De udbredte seksualmoralske standpunkter udspringer af (hetero) normative grundopfattelser af sex, der bifalder en hierarkisering og normalisering af seksuelle lystfølelser og kropsudfoldelser. Analsex er fx mindre acceptabelt end vaginalt samleje. Men hvorfor er det mere legitimt, at unge dyrker vaginalt samleje end analsex? Er det måske, fordi "rigtig" sex alligevel helst skal organiseres efter den tidligere så ophøjede, nu forslidte heteroseksuelle fortælling om, at sex er lig med vaginalt samleje mellem kvinde og mand - helst med samme alder, sociale og etniske baggrund? Bemærk: Jeg advokerer ikke for, at analsex er et universalt wonder drug, som alle kvinder skal have smag for, men at kvinder generelt ikke skulle have lyst til analsex, og heller ikke dyrker det, med mindre det er tvang, er der ikke faktuelt belæg for (jf. Graugaard 2006; Hald 2007; Hardy 2006). Analsex er bestemt heller ikke, trods dens popularitet $i$ dele af nutidens pornografi, en seksuel praksis, som pornografien har opfundet for at undertrykke kvinder; tilsyneladende 'overser' en række debataktører analseksualitetens historisk stærke position fra antikken og frem.

Vælger kvinder at dyrke eller interessere sig åbent for nogle af disse fordømte og upassende seksuelle lystfølelser og kropsudfoldelser, mødes de ofte med mistænkeliggørelse og stigmatiserende holdninger som syge, som ofre og undertrykte af pornografien og mænds seksuelle lyster. Som eksempel skabte Kira Eggers udtalelse i 2004 om at hun ville lave pornofilm med voldtægtsfantasier vrede kommentarer fra flere kvindelige debattører. Stand up-komikeren Lotte Heise udtalte: "Bare fordi hun har et betændt seksualliv, så behøver vi andre ikke have det". Et andet eksempel 
på de kategoriske og normative udsagn om kvinders seksualitet kom fra en sexolog, der foreslog at indarbejde en norm for kvindelig seksualitet $\mathrm{i}$ loven om voldtægt, således at hvis kvinder anklagede mænd for gruppevoldtægt, kunne man uden videre antage at det havde sin rigtighed, fordi det ifølge sexologen lå inden for "almindelige normer", at kvinder ikke kunne finde på at være sammen med flere mænd på samme tid. Som et tredje eksempel på de essentialistiske og normative standpunkter om, at kvinder er seksuelt ens og deres seksualitet er væsensforskellig fra mænds, kan nævnes kønsforskeren Anette Dina Sørensen, der udtalte: "Man kan diskutere, om kvinders seksualitet er blevet anerkendt $\mathrm{i}$ den danske seksualitetskultur: meget tyder på, at det er den mandlige seksualitet, og det mandlige begær, der i fokus. Har det måske nogensinde været in med et langt forspil?”

\section{2.... og forbud og regulering}

Debatten i 2004-2006 var også præget af mange krav om forbud, censur og regulering af seksuelle lystfølelser og kropslige udfoldelser. Foruden forslaget om kriminalisering af købesex blev der fremsat krav om helt at forbyde prostitution; krav om påsætning af pornofiltre på offentlige computere; krav om forbud mod reklamer med nøgenhed og seksualisering; forslag om, at bibliotekarer skal klippe sexannoncer ud af aviserne, før de lægges frem i bibliotekernes læsesale; krav om helt eller delvist forbud mod pornografi; forslag om, at folketingspolitikere skal skrive under på, at de ikke går til prostituerede, når de er ude at rejse med Folketingets penge; krav om pornografifordømmende seksualundervisning i skolerne; forslag om, at forældre skal overvåge deres børns og unges tv-kiggeri og fortælle dem, hvad der er rigtigt og forkert, og turde sige nej, så de ikke gør ting, "forældrene ikke har lyst til at de skal gøre"; forslag om, at kunne dømme mænd for 'uagtsomme voldtægter'. Summa summarum: Inden for tiåret 1997 til 2004-2004 skete der et markant skift og en bevægelse i de artikulerede holdninger og standpunkter om analsex, gruppesex, pornografi, seksualisering og prostitution i de trykte medier. Debatten i 2004-2006 var domineret af mere restriktive og invaderende seksualmoralske - eller seksualmoralistiske - standpunkter, der vil opstille regler, indføre forbud, censur og normer for, hvilke seksuelle lyster og kropsudfoldelser kvinder, mænd, unge og voksne må nyde og dyrke med hinanden. Før jeg udfolder, hvad jeg mener med seksualmoralisme og (hetero)normativitet, skal vi se 
nærmere på den radikale ændring af debatklimaet i seksualdebatten fra 1997 til 2004-2006.

\section{En antagonistisk debat}

Selv om de mest udbredte standpunkter i 2004-2006 således artikulerede bekymring, frygt og fordømmelse, samt krav om forbud, kontrol og regulering, var der også repræsenteret en anden og mindre udbredt strømning af holdninger og positioner. I disse standpunkter udtryktes et mere positivt, afslappet og nysgerrighedsbåret grundsyn på seksuelle lyster og kropslige udfoldelser, som lå helt på linje med de fremherskende standpunkter i 1997. Man stillede sig kritisk over for positioner, der anså fx analsex, gruppesex og pornografi for kvindeundertrykkende og skadelig for unge per se. Man opponerede mod generaliserende og essentialistiske synspunkter, der a priori antager, at kvinder ikke har lyst eller kunne få lyst til at dyrke gruppesex eller se porno; man markerede modstand mod forbud, censur og restriktion på seksualitetens område.

Et særligt mønster i 2004-2006-debatten trådte tydeligt frem: En seksualdebat, der stod stærkt polariseret mellem de to antagonistiske fronter. På den ene side finder man de dominerende hovedstandpunkter, som er drevet af bekymring, ængstelse og frygt for - og ofte et negativt og fordømmende syn på - analsex, gruppesex, pornografi og seksualisering, som man mener er 'farligt' og 'undertrykkende'. På den anden side finder man en samling af artikulationer og standpunkter, der forholder sig mere positivt, afslappet og ikke-fordømmende til seksuelle emner, som man mener kan være 'frigørende' og ikke grundlæggende er 'problematiske'. De ideologiske fronter og standpunkter i debatten kan også ses som en alliance af konservativ-religiøse og radikalfeministiske holdninger over for liberale og 'frisindsorienterede' standpunkter (jf. Synnevåg 2002).

Debatten var først som sidst domineret af disse indbyrdes stridende standpunkter og styret af en mærkværdig logik, der afkræver, at alle der deltager i debatten, melder sig på banen som enten for eller imod pornografi, købesex eller analsex. Dette sort-hvide debatklima skyldtes, at seksualdebatten i 2004-2006 i langt højere grad foregik inden for moralens horisont. Her er man orienteret mod at vurdere, værdisætte og rangordne seksuelle lystfølelser og kropsudfoldelser med det snævre svarrepertoire: ja eller nej. De stærkt antagonistiske synspunkter og dualistiske positioneringer - undertrykkende/frigørende - i debatten om seksuelle lystfø- 
lelser, pornografi og prostitution er en arv fra de såkaldte sexwars i USA og England fra slut-1970'erne og 1980'erne. Disse har domineret den angelsaksiske og, i varierende grad, de internationale feministiske debatter i akademia og det offentlige rum om disse emner siden HER MANGLER NOGET (Paasonen 2009; Lykke 2008) - således i midt- og sen-00'erne tilsyneladende også i Danmark. Vi kender til hudløshed spørgsmålene: Er analsex kvindeundertrykkende, eller er det udtryk for kvinders seksuelle frigørelse? Er kvindelige (og mandlige) deltagere i pornografi undertrykte ofre, eller er de entreprenante seksuelle eventyrriddere? Disse enten/ellerspørgsmål kræver, uanset om de formuleres af en seksualitetsforsker eller en velmenende samfundsborger, altid et ja- eller nej-svar (Albury 2003; 2009).

Når seksualdebatten foregår inden for moralens ensidige, polariserende og dualistiske horisont, er der ikke plads til mellempositioner, nuanceringer og både/og'er. Den moralske ramme, som debatten føres inden for, er også problematisk for begge hovedstandpunkter. Argumenterer man for et 'ja' til seksuelle lystfølelser og kropsudfoldelser i 'frigørelsens' navn, risikerer man at få skudt i skoene, at man hylder en rendyrket privatisering eller relativisering af moralen, eller ligefrem plæderer for umoral. Man falder også nemt i den fælde at argumentere for, at frigørelse af 'seksualitet' og 'begær' er menneskers lykkelige endestation - friheden hinsides hierarki og magtrelationer (jf. Foucault). Argumenterer man for et 'nej'

til seksuelle lystfølelser og kropsudfoldelser i 'undertrykkelsens' navn, er problemet, at det fører til seksualmoralisme og (hetero)normative seksualitetsopfattelser, som har haft stærk fremgang i den danske debat i midtog sen-00’erne.

I de følgende afsnit bringes begrebsparret moral og etik i spil til dels at afklare min anvendelse af begreberne seksualmoralisme og (hetero)normativitet, og til dels at anskueliggøre, hvordan etikkens perspektiv udgør en alternativ forståelses- og analyseramme i forhold til den moralske horisont, som midt- og sen-00'ernes seksualdebat er orienteret efter. Foucault er den teoretiske hovedinspiration med sin altid subtile sensitivitet og vagtsomhed over for normative strømninger, social kontrol og normalisering af enhver art på det seksuelle og kropslige område.

\section{Moral og etik: Du skal, du må ikke!}

I sin trebinds undersøgelse af Seksualitetens historie fra 1976 foretager Fou- 
cault bl.a. en række studier af afgørende forandringspunkter i det moralske forhold til seksuelle nydelser og kropsudfoldelser fra den moderne, vestlige verdens seksualitets-, begærs- og selvinstallation og -erfaring tilbage til antikken (Foucault 2006; 1992; 2004). En afgørende pointe hos Foucault er, at de moralske bekymringer om seksuelle lystfølelser og kropsudfoldelser, der involverer kønsorganerne, og den problematisering de gav anledning til i både den antikke og den kristne-moderne vestlige kultur, har antaget forskellige former og udmøntet sig i forskellige slags moralforskrifter.

I analysen af antikken i bind II af Seksualitetens historie indfører Foucault en skelnen mellem moral og etik, der skal ses i sammenhæng med, at han på samme tid redefinerer sit socialkonstruktionistiske analyseblik (i forhold til bind I) fra at være diskursorienteret til i højere grad at være socialfanomelogisk. Projektet drejer sig nu om at undersøge, hvordan mennesker historisk er kommet til at erfare og erkende sig selv som subjekter for og med en 'seksualitet' og et 'begær'. Foucault lancerer hermed et dobbelt analysegreb: På den ene side er 'seksualiteten' og 'begæret' - udefra set - særlige historiske installationer ('dispositif'/'apparatus') i moderne samfund, der bl.a. via medicinske og andre videnskabelige diskurser, institutioner, praktikker og teknikker - og drevet af livsmagten ${ }^{44}$ - gennemtvinger en samfundsmæssig organisering, værdisætning og hierarkisering af sociale praksisser, seksuelle lystfølelser og kropsudfoldelser i gode/ onde, normale/unormale, gode/dårlige. På den anden side er 'seksualiteten' og 'begæret' - indefra set - også en særlig erfaring og oplevelse ('expérience'/'experience') hos det enkelte individ (Foucault 1992: 5ff, 251ff; 2000c: 263; Dreyfus \& Rabinow 1982: 177; Bech 1989). Jeg skal vende tilbage til dette dobbelte analysespor.

Moral hidrører ifølge Foucault fra det moralsystem, der har udviklet sig fra den kristne epoke til den moderne vestlige kultur (og den moderne begærs- og seksualitetsinstallation), hvor seksuelle nydelser og kropsudfoldelser er blevet et område reguleret af universelle lovmæssige regler, påbud og forbud: Du skal, du må ikke! - orkestreret udefra/ovenfra af en abstrakt autoritet - først kirken og siden den moderne statsmagt. Moral defineres således som forskrifter om, hvad der er tilladte og forbudte handlinger, og som bestemmer hvilke seksuelle lystfølelser og kropsudfoldelser, der tildeles positiv eller negativ værdi, som alle forventes at rette sig efter og som skal sanktioneres af en stor magt: kirken eller staten.

Den moderne epokes moralske orientering markerer også et særligt 
forhold til de seksuelle lystfølelser og nydelser ('pleasure'), som i den kristne epoke og moderne vestlige kultur knyttes til begæret ('desire'). I moderne tid forankres 'begæret' som en del af menneskets biologiske beskaffenhed, eller evt. som noget, der er tidligt etableret i barndommen og helt væk er al talen om seksuelle lystfølelser! Til forskel fra antikken bliver seksuelle lystfølelser og kropsudfoldelser nu ikke set som handlinger i bestemte situationer, men kobles til hele personen og en dybereliggende mening: Formål, betydning og årsag til seksuelle og kropslige tilbøjeligheder skal nu findes i personens indre, i 'seksualiteten', 'begæret' og selvet (fx den homoseksuelle). Der sker således et skifte fra variationer i handlinger til afvigelser i identitet (Foucault 2006; 1992; 2000b; 2000c).

I antikken er holdningerne til seksuelle lyster og kropsudfoldelser derimod ikke givet gennem begærs- og seksualitetsinstallationer eller et moralsystem, der baserer sig på påbud, forbud og restriktion. Alle seksuelle lyster er i den forstand tilladte, men de er reguleret via nogle personlige moralprincipper - etikken, som har at gøre med den personlige ansvarlighed og omsorg for sig selv og andre. Etikken er selvets praksisser uden om de store magtinstitutioner. Det er en moralsk regulering, hvor den enkelte selv forventes at opstille passende rammer og retningslinjer for sig selv, sine handlinger og sit samvær med andre mennesker og udforme sit liv som et kunstværk og eksistens-æstetik i overensstemmelse med nogle udbredte idealer om den smukke livsførelse (Foucault 1992; 2000c).

\section{Seksualmoralisme - moralens ekstreme tvilling}

Foucaults kritiske perspektiver på den moralske horisonts indflydelse i moderne samfund peger væk fra en autoritativ, påbydende og forbydende (seksual)moral og frem mod en personlig etik/moral. Foucaults sondring mellem moral og etik åbner ligeledes - inspireret af den amerikanske queerteoretiker Michael Warner (1999), den danske sociolog Henning Bech (2009), den amerikanske queerfeminist Gayle Rubin (1984) og den franske sociolog Michel Maffesoli (1991) - for en yderligere distinktion mellem moral/etik og moralisme. På den ene side er der etik og moral, som er personligt og privat funderede holdninger til, hvordan man forholder og danner sig ansvarsfuldt og myndigt i forhold til sine lyster. Synet på seksuelle lystfølelser og kropsudfoldelser er i denne etiske ramme orienteret efter bl.a. et princip om seksuel variation og forskellighed (Rubin 1984), et æstetisk-eksistentielt perspektiv på seksuelle og kropslige lyster (Bech 
2009:18ff) og en (ud)dannelse på det seksuelle og erotiske område, der lægger vægt på netop personlig dannelse, refleksivitet, handlekompetence og nysgerrighedsbåren dialog (Graugaard 2010:252-3; Graugaard \& Roien 2007:318-9).

Moralisme - eller seksualmoralisme - er, som moralens ekstreme tvilling (jf. Jakobsen 2004:196), på den anden siden, når nogen udefra/ovenfra (fx kirken, politikerne, feminister) vil dømme, værdisætte, hierarkisere og opstille specificerede regler (gennem påbud og forbud) for selvets/andres seksuelle lystfølelser og kropsudfoldelser samt sanktionere dem af en stor magtinstans: staten. Seksualmoralistiske standpunkter rejser således krav om, at værdisætningen, hierarkiseringen og normaliseringen af seksuelle lystfølelser og kropsudfoldelser i 'gode', 'sunde', 'normale' og 'rigtige' skal påtvinges alle som en (påbud) og følges op med det mest vidtgående regulerings- og sanktionsmiddel, som staten har til sin rådighed: forbud og kriminalisering. Seksualmoralisme er særlig ekstreme og restriktive holdninger, som er orienteret efter moralens påbydende og forbydende horisont, der grundlæggende er baseret på at fælde ultimative og generelle domme og foretage vurderinger over selvet og andre (Connolly 1993; Albury 2009). Som mine analyser viser, baserer seksualmoralistiske standpunkter sig ofte på dels essentialistiske antagelser om, at menneskers seksualitet (som kvinder, mænd, unge, voksne etc.) er og skal være på en bestemt måde og grundlæggende er og bør være ens. Og de baserer sig dels på heteronormative opfattelser eller i bredeste forstand: normative standpunkter i forhold til seksuelle og kropslige lyster og handlinger med krav om en normalisering af menneskers sexliv ud fra nogle bestemte normer og konventioner ikke bare om køn, seksualitet og etnicitet, men også om alder, geografi (by/land), livsførelse, livsbaner, temporalitet, ungdom, barndom, voksenhed, alderdom, fritidsvaner etc. (jf. Halberstam 2005).

\section{Etikken - mellem magt og frihed}

Med etikken anviser Foucault en mulighed for, at seksuelle lystfølelser og kropsudfoldelser ikke bliver reguleret gennem forbud, der er enten religiøst, politisk eller moralsk begrundede. Etikken som alternativ tager afsæt i en positiv og balanceret brug og udfoldelse af de lyster, som den enkelte kan indpasse i sin livsførelse afstemt efter et ideal om det smukke liv. Frihedspraksisser er den term, Foucault foretrækker at bruge om etikkens potentiale for at øge den menneskelige frihed og mindske kontrol og 
undertrykkelse. Etikken eller den etiske sensibilitet er den praksisform, som friheden kan tage, når den er oplyst af refleksion - dvs. når tænkning, erfaringer og samtale i de hverdagslige situationer konstant inddrages for at bestemme fremtidige handlinger. Modsat moralske domme, der er nedlagt udefra, er etiske domme personlige og baseret på kontekst og konkrete omstændigheder (Foucault 2000a; Mühleisen 2007; Connolly 1993; Albury 2003).

Den etiske horisont for menneskers handlinger og nydelser skal ikke forveksles med en magtfri seksualitet eller frigorelse af 'seksualiteten' og 'begæret', som Foucault jo selv viste med sin afvisning af repressionshypotesen. 'Frigørelse' er ikke menneskets totalt frie og lykkelige endestation, men er snarere udsigtspunkt til nye magtrelationer. Det er dog ikke kun negativt. (Livs)magten er en produktiv og flydende kraft - og er ikke mulig at indfange med statiske hierarkiske-dikotomiske analysemodeller. Magten ændrer hele tiden retning og skifter hænder, forandrer position og varierer $\mathrm{i}$ intensitet (Foucault 2006; Albury 2009; Heinskou 2010). Magt er således både tyngende og mulighed - og ikke en statisk dikotomisk-hierarkisk størrelse. Foucault ser seksuelle lystfølelser og kropsudfoldelser som en væsentlig og dynamisk del af vores kultur. Han opfordrer til, at vi - som lystens fænomenologer - opdyrker og skaber nye muligheder for seksuelle og kropslige lyster, en ars erotica, som 'begæret' kan vokse af (Foucault 2000b:166).

Foucaults socialfænomenologiske analysespor gør os i stand til at kaste blikket på historiske former for levet sanset liv og anskue 'seksualiteten' og 'begæret' som dimensioner ved - med et begreb fra Martin Heidegger - væren-i-verden, eller væren-i-intertelebyen, når det gælder den nuværende senmoderne kontekst, der er knyttet til stemning, rum, materialitet, æstetik, køn og socialitet (Bech 2005a). Dette perspektiv åbner således mulighed for en anden etisk orienteret nydelsesøkonomi, hvor seksuelle lystfølelser og kropsudfoldelser løftes ud af den moderne begærsinstallation og kravet om, at lysterne har et formål, en årsag og skal underkastes en 'begærets hermeneutik'. Seksuelle og kropslige lyster konstitueres her som grundlæggende meningslose og som 'overfladiske' og løsslupne (op) stemtheder, som vi kreativt og dynamisk leger og spiller med i seksualiserede og kønnede spil om seksuel nydelse og lyst i byen, på diskotekerne og i de virtuelle omgivelser (jf. Bech 2005a; Graugaard 2010: 243; se også Stenslund 2009). Fra et kønsperspektiv afløses konskamp (baseret på forestillingen om et dybt og strukturelt forankret dikotomisk hierarki mellem mænd 
og kvinder/andre køn) af mere ligeværdige seksualiserede konsspil, men denne etiske socialitetsform mellem kønnene er ikke fri af den dynamiske og flygtige magt og viser sig fx i lysten til forskellighed, lysten til objektivering, lysten til magt (jf. Heinskou 2010).

Der findes i litteraturen naturligvis forskellige opfattelser og kritiske vurderinger af, hvad man skal lægge i den græske etik og tanken om et mere aktivt skabende subjekt i Foucaults sene værk (fx Raffnsøe et al 2009: $229 \mathrm{ff}$ ). Det er vigtigt at holde sig for øje, at Foucault ikke forestillede sig, at man kunne 'spole' det moderne samfund tilbage til den græske antik og etik, og heller ikke fandt det ønskværdigt på grund af det græske samfunds patriarkalske og herre-slave-struktur. Min anvendelse af Foucaults sondring mellem moral og etik har både et filosofisk-analytisk og historisk-politisk niveau: Jeg ser dels Foucaults etiske sensibilitet som en frugtbar analyseramme og forståelseshorisont for seksualitetsfænomener i senmoderne kontekster. Her er vægten ikke lagt på aprioriske moralske domme om fænomener og adfærd, men på en etisk sensibilitet og nysgerrighed over for kompleksiteten, ambivalenserne og perspektiverne i konkrete kontekster og menneskers egne oplevelser og følelser, hvilket jeg skal uddybe nærmere i det afsluttende afsnit. Jeg forfølger dels Foucaults egen opfattelse af den græske etik som et positivt alternativ til en tvingende og universel forbudsmoral, der passer bedre til senmoderne sekulariserede samfund ( $\mathrm{fx}$ Foucault 2000c:255ff; 2000a:283). En opfattelse, som man får et klarere indtryk af, når man - som Bech (1989) bemærker - læser Foucaults debatindlægog interviews. Foucault peger på, at en autoritativ og disciplinerende påbuds- og forbudsmoral på det erotiske område siden 1960'erne - $\mathrm{i}$ hvert fald $\mathrm{i}$ visse perioder og visse steder - har været ved at erodere $i$ senmoderne vestlige kulturer. Danmark er formentlig et af de steder i den vestlige kultur, hvor den moralske horisont og restriktive forbudsmoral på det seksuelle område siden 1960'erne er trådt mest i baggrunden - indtil altså midt- og sen-00'erne, som vi skal se nærmere på i næste afsnit.

\section{Den danske seksualdebat før og nu}

Den etiske orientering, som Foucault skitserer, har nok frem for påbudsog forbudsmoralen været mere kendetegnende for de fremtrædende seksualmoralske standpunkter og ideologier i det sekulariserede Danmark fra 1960 'erne og frem. De færreste mennesker har følt deres etik begrundet i religion eller en udefra given instans, og de færreste har ønsket, at sta- 
ten eller myndigheder skulle gribe ind i deres moral eller privatliv. Der har været en udbredt konsensus om i vidt omfang at lade kvinder og mænd leve deres liv, som de ønsker, uden statslig indblanding, men med frihed under ansvar til at vælge og dyrke forskellige former for seksuel adfærd og levevis. En række forhold har været afgørende for denne udvikling: Udover den overordnede ramme, som velfærdsstat, socialt sikkerhedsnet og udligning af sociale kønsforskelle, er der frigivelsen af p-pillen og pornografien, kvindebevægelse og homobevægelse, samt afkriminalisering af prostitution.

Et andet forhold er også vigtigt: Danmark har ikke - på linje med andre af de nordiske lande - været invaderet af de såkaldte sexwars fra USA og England fra slut-1970'erne og start-1980'erne (Paasonen 2009). Den danske feministiske debat og forskning har heller ikke - trods påvirkning fra angelsaksisk feminisme - overtaget den radikalfeministiske seksualmoralistiske kritik, der tematiserer seksuelle lystfølelser, pornografi og prostitution som mænds undertrykkelse af kvinder, og som kræver forbud mod prostitution, pornografi og forskellige seksuelle lyster. Der har i Danmark - modsat fx USA jævnfør de føromtalte sexwars (se fx diskussioner hos Butler 2007; Rubin 1984; 1993) og Sverige (se Kulick 2005; Östergren 2006) - ikke været artikuleret nogen udbredt kritik eller bekymring, hverken i medierne eller i akademia, af fænomener som pornografi, prostitution, seksualisering eller sex gennem 1980'erne, og ej heller i 1990'erne, hvor seksualiseringen af det offentlige rum og pornografiens indtrængen i hverdagslivet og billedmedierne tog til i Danmark måske mere end noget andet sted i verden (Bech 2005a; 2005b). Min tekstanalyse af de trykte medier i 1997 bekræfter i det store og hele dette billede af en etisk snarere end moralsk orienteret offentlig seksualdebat i Danmark. Der var mere eller mindre enighed om, at kvinder generelt er udstyret med en evne til at erfare seksuel lyst og være selvstændige seksuelle aktører - også selv om de skulle finde på at deltage i eller se pornografi eller have lyst til analsex. Vi har ikke i samme grad som Sverige og USA set en moralsk kamp mellem en naturlig kvindelig god seksualitet og en objektiverende ond mandlig seksualitet (jf. Albury 2003).

Efter årtusindskiftet og specifikt fra 2004 til 2006 viser min tekstanalyse, at bekymring, negative og fordømmende holdninger over for visse seksuelle lyster og handlinger er blevet et særdeles fremtrædende og faktisk det dominerende standpunkt i medierne. Hvornår dette skift mere præcist indtræffer, er svært at fastslå. Min undersøgelse viser, at der er sket 
et radikalt skift i synet på pornografi, analsex, gruppesex og prostitution inden for et tiår, og at der kan registreres et stigende antal artikler om pornografi, prostitution, seksualisering etc. fra $2000 \mathrm{og}$ frem. Netop dette år opstod der en større debat og kritik af seksualisering og pornoficering i det offentlige rum og pornografi i medierne i Danmark. Samme år stiftedes foreningen Pornofrit Miljø. Omkring årtusindskiftet artikulerede en række feministiske og nyfeministiske stemmer sig også i debatbøger, antologier og avisdebatter med kritik af og modstand mod bl.a. pornografi, prostitution og seksualisering og pornoficering i det offentlige rum. Disse aktører har også været toneangivende stemmer i den offentlige debat i 2004-2006 (Bech 2005a:289ff; Mühleisen 2007:178).

Vi ser den moralske horisonts genkomst i midt- og sen-00'ernes seksualdebat med dens krav om vurdering, domfældelse, påbud og forbud. Som min analyse viser, synes de senere års dominerende seksualmoralske standpunkter at kunne spores tilbage til den angelsaksiske radikalfeminismes hierarkiserede dikotomiske syn på forholdet mellem kvinder og mænd. I denne tankegang udøver mænd altid magt, kontrol, dominans og undertrykkelse af kvinder, hvorfor seksuelle fænomener anses for per se kvindeundertrykkende, og derfor over en kam skal forbydes. At der således ligger en radikalfeministisk seksualmoralisme - blandet med essentialistiske og heteronormative opfattelser - bag de fremherskende seksualmoralske standpunkter i debatten i 2004-2006, viser sig også, når vi ser på, hvilke aktører der artikulerede sig i debatten. De udbredte bekymringer, frygten og de restriktive seksualmoralske standpunkter artikuleredes ikke bare af konservativ-religiøse kredse, men af en bred skare af opinionsdannere - feminister, forskere, avisredaktører, eksperter, socialarbejdere, psykologer, læger; foreninger som Pornofrit Miljø og KFUK Reden; feministiske organisationer, som Kvinderådet og Selskabet for Ligestilling, samt politikere, politiske netværk og politiske partier fra centrumvenstrefløjen. Artikulationerne kom især fra en vidensmæssig 'elite' uddannet på universiteter og højere læreranstalter, som er med til at sætte den politiske dagsorden. Som moralske entreprenører - dvs. som 'regelskabere' og/eller 'regelhåndhævere' (Becker 2005) - spiller de en stærk rolle i defineringen af, hvad der i Danmark betragtes som 'undertrykkelse', 'sociale problemer', 'sociale afvigelser' og 'normalitet'. I den forbindelse er det vigtigt at erindre om undersøgelsens afsæt i debatten i avismedier, hvor man må forvente, at særligt magtudøvende instanser, fx politikere, opinionsdannere, feministiske interesseorganisationer mv. kommer til orde. Men der 
er ikke nødvendigvis overensstemmelse mellem mediernes skriverier og hvad der rører sig i bredere kredse af befolkningen. Eksempelvis peger opinionsundersøgelser på, at der ikke er flertal i befolkningen for at forbyde købesex, som flere feministiske grupper og politiske partier, bakket op af rockstjerner, chefredaktører, studieværter og fagforeningsbosser, ellers har ført kampagne for i flere år. Selv om debatten om analsex, gruppesex, pornografi og prostitution i de trykte medier i disse år synes at foregå inden for en moralsk og bekymret horisont med en overvægt af seksualmoralistiske standpunkter, kan holdningerne til seksuelle lystfølelser og kropsudfoldelser hos befolkningen i bredere forstand godt være mere afslappede og nysgerrigt forankret i etikkens perspektiv, hvilket en tur på nettet hurtigt kan forvisse en om.

\section{Etisk sensibilitet som analysetilgang}

Afslutningsvis vil jeg uddybe, hvordan vi kan lade os inspirere af Foucaults perspektiv om etikken og en etisk sensibilitet som en alternativ forståelseshorisont og analysedagsorden i forhold til den moderne moralske tilgang til og problematisering af 'seksualitet' baseret på universelle regelsætninger, værdivurderinger, påbud og forbud. Det etiske perspektiv er både frugtbart som forståelseshorisont $\mathrm{i}$ forhold til den måde vi forholder os til vores egne og andres seksuelle og kropslige lyster og som en analyseramme, når man vil undersøge seksuelle fænomener i en senmoderne samfundskontekst. En forsker, der tager afsæt $i$ en etisk sensibilitet $i$ undersøgelser af fx pornografi og unges interesse for analsex, får en sensitivitet og et blik for at forstå kompleksiteten, ambivalenserne - det dynamiske forhold mellem undertrykkelse og frigørelse, magt og frihed, de konkrete kontekster, menneskers egne refleksioner, følelser og ønsker.

I et etisk analyseperspektiv er spørgsmålet ikke længere, om fx pornografi eller en seksuel praksis som analsex er undertrykkende, men om de produceres og konsumeres eller foregår i en etisk kontekst ud fra kriterier om frivillighed, arbejdsbetingelser, løn mv. (Albury 2009). Med en etisk sensibilitet gør man sig i stand til konkret at undersøge folks glæde ved fx pornografi, deres brug af pornografi, deres etiske overvejelser omkring de mennesker der indgår i pornografi, den mening og placering, som pornografien har i deres liv. Det peger væk fra en udbredt opfattelse af pornografien - i dens mange genrer og udformninger - som en (porno)inficering eller invasion og hen mod en konversation om det på samme tid så stærkt appellerende og fascinerende $\mathrm{og}$ bekymrende ved pornografien. Her fældes ikke udefra nogen generaliserende 
moralske domme (for/imod), men i stedet foretages etiske vurderinger på baggrund af en flerdimensionel tilgang til kontekst, mening, menneskers erfaringer og refleksioner. Denne tilgang er derimod åben for en (måske frugtbar) udvikling hen mod en post-pornografisk æra, hvor opdelingen mellem privat og offentlig, som pornografien er skabt af, eroderer, og hvor de rigide rollefordelinger i 'konsumenter' og 'producenter' af porno opblødes til mere demokratiske udvekslinger af lyst som 'prosumenter' på nettet, som det ses i amatørpornogenren (jf. Kendrick 1996; Bell 2006). På samme måde giver den etiske sensibilitet mulighed for at indlede en nysgerrig og interesseret dialog om de seksuelle lystfølelser, deres æstetiske kvaliteter og passende udfoldelse sammen med andre, som skyder frem i de interteleurbane rum - også dem af mere uforpligtende, intens, eksperimenterende og objektiverende karakter.

\section{Noter}

1 Alt, hvad der står i “anførelsestegn" i artiklen, er - med mindre andet er angivet hentet fra min undersøgelse, hvor der findes en meget grundig kildehenvisning i forhold til citater mv. (Wøldike 2009).

2 For så vidt angår de udvalgte seksuelle temaer, er al tekst fra de fleste og vigtigste offentlige skrevne medier i Danmark i 2004-2006 og 1997 inddraget i tekstanalysen. Analysens samlede tekstmateriale andrager således over 6.000 avisartikler og læserindlæg.

3 For specifikke detaljer om undersøgelsen, dens design, tekstanalysestrategi og metoderefleksioner henvises den kritiske og nysgerrige læser til selve undersøgelsen (Wøldike 2009).

4 Et væsentligt led i disse installationers fremkomst er livsmagten, der ifølge Foucault opstår fra 1800-tallet i de moderne vestlige stater. Her er tale om en ny og produktiv form for magt, der retter sig mod selve livet og kroppen ved at disciplinere individerne og befolkningen med henblik på at optimere deres samfundsmæssige virke og nytte. Livsmagten vinder ikke sin styrke ved at blive påduttet oppefra af en absolut magt, men udvikler sig til et større og uintenderet magtkompleks og netværk ud af de utallige forskellige relationer, uligheder i styrkeforhold, intentioner og adfærd som mennesker og institutioner indgår i (Foucault 2006:111ff; 1977b:196ff). 


\section{Litteraturliste:}

Albury, Kath (2003): "The Ethics of Porn on the Net" i Lumby, C. and Probyn, E. (red.), Remote Control: New Media, New Ethics, Melbourne: Cambridge University Press, s. 196211.

Albury, Kath (2009): 'Reading Porn Reparatively", Sexualities, vol. 12, nr. 5, s. 647-653

Bech, Henning (1989): "Skal man være sig selv? Om Foucaults seksualitetshistorie", Nordisk Sexologi, 8/1989. SIDETAL MANGLER

Bech, Henning (2005a): Kvinder og mand, København: Hans Reitzels Forlag.

Bech, Henning (2005b): 'Hierarki, dikotomi etc.: Om den store fortælling om køn, seksualitet, etnicitet osv., samt om nogle mulige mellemstore alternativer', Bech, Henning og Sørensen, Anne Scott(red.), Kultur på kryds og tvars, Århus: Forlaget Klim.

Bech, Henning (2009): Seksualitetsforskning. En introduktion, København: SEKSUALITETER (Skriftrække fra Center for Seksualitetsforskning), nr. 1.

Becker, Howard S. (2005, [1963]): Outsidere. Studier i afvigelsessociologi, København: Hans Reitzels Forlag.

Bell, David (2006): 'Bodies, Technologies, Spaces: On 'Dogging”' i Sexualities, vol. 9, nr.4. SIDETAL MANGLER

Butler, Judith (2007, [1994]): 'Opposition mod passende genstandsfelter' i Søndergaard, Dorte Marie (red.) Feministiske tænkere. En tekstsamling. København: Hans Reitzels Forlag, s. 75-106.

Connolly, William E. (1993): "Beyond Good and Evil. The Ethical Sensibility of Michel Foucault", i: Political Theory. Vol. 21. No. 3, s. 365-389.

Dreyfus, Hubert \& Rabinow, Paul (1982): Michel Foucault: Beyond Structuralism and Hermeneutics. Chicago: The University Press of Chicago.

Foucault, Michel (2006 [1976]): Viljen til viden. Seksualitetens historie I. København: Det lille forlag.

Foucault, Michel (1992 [1985]): The Use of Pleasure. The History of Sexuality. Vol. II. London: Penguin Books.

Foucault, Michel (2004 [1984]): Omsorgen for sig selv. Seksualitetens historie III. København: Det lille forlag.

Foucault, Michel (2000a [1984]): 'The Ethics of the Concern for Self as a Practice of Freedom', i: Rabinow, Paul (ed.): Ethics. Subjectivity and Truth: The Essential Works of Foucault 1954-1984. Vol. I. London: Penguim Books.

Foucault, Michel (2000b [1982]): 'Sex, Power, and the Politics of Identity', i: Rabinow, Paul (ed.): Ethics. Subjectivity and Truth: The Essential Works of Foucault 1954-1984. Vol. I. London: Penguim Books.

Foucault, Michel (2000c [1983]): 'On the Genealogy of Ethics: An Overview of Work in Progress', i: Rabinow, Paul (ed.): Ethics. Subjectivity and Truth: The Essential Works of Foucault 1954-1984. Vol. I. London: Penguin Books.

Graugaard, Christian (2006): 'Mænd og seksualitet', in: Christensen, Kaare et al. Kend din krop, mand. København: Aschehoug Egmont. 
Graugaard, Christian \& Roien, Line Anne (2007): "Didactic perspectives on pornography", in: Knudsen, Susanne et al (eds.) Generation P? Youth, Gender and Pornography. København: Danmarks Pædagogiske Universitetsforlag.

Graugaard, Christian (2010): "Vokseværker. Et signalement af unge danskeres seksuelle liv", in Psyke \& Logos. 2010, 31, s. 232-256.

Hald, Gert Martin (2007): 'Pornography Consumption: A Study of Prevalence Rates, Consumptions Patterns, and Effects. Psykologisk Institut, Aarhus Universitet, Århus.

Halberstam, Judith (2005): In a Queer Time \& Place. Transgender Bodies, Subcultural Lives. New York and London: New York University Press.

Hardy, Simon (2006): 'Anal sex. Phallic and other meanings', i: Seidman, S., Fischer, N. \& Meeks, C.: Handbook of the New Sexuality Studies. London: Routledge.

Heinskou, Marie Bruvik (2010): En kompleks affare. Anmeldte voldtagter i Danmark. Ph.d.afhandling, Sociologisk Institut, Københavns Universitet."

Jacobsen, Michael Hviid (2004): Zygmunt Bauman - den postmoderne dialektik. København: Hans Reitzels Forlag.

Kendrick, Walter (1996): The Secret Museum: Pornography in Modern Culture. University of California Press.

Kulick, Don (2005): 'Four Hundred Thousand Swedish Perverts', i: GLQ, 11(2).

Lykke, Nina (2008): Konsforskning. En guide til feministisk teori, metodologi og skrift. Frederiksberg: Samfundslitteratur.

Maffesoli, Michel (1991): 'The Ethics of Aesthetics', i: Theory, Culture \& Society 8(1), 1991, s. 7-20.

Mühleisen, Wencke (2007): "Mainstream Sexualisation and the Potential for Nordic New Feminism”, i: NORA - Nordic Journal of Women's Studies. Vol. 15, No. 2-3, s. 172-189.

Paasonen, Susanna (2009): "Healthy Sex and Pop Porn: Pornography, Feminism and the Finnish Context”, i: Sexualities. Vol 12(5), s. 586-604.

Raffnsøe, Sverre, Gundmand-Høyer, Marius og Thaning, Morten (2009): Foucault. Frederiksberg: Samfundslitteratur.

Rubin, Gayle (1984): 'Thinking sex: Notes for a Radical Theory of the Politics of Sexuality', i: Vance, Carole S. (ed.): Pleasure and Danger: Exploring female Sexuality. London: Routledge, s. 267-319.

Rubin, Gayle (1993): "Misguided, Dangerous, and Wrong: an Analysis of Anti-pornography Politics”, i: Assiter, Alison and Carol, Avedon: Bad Girls and Dirty Pictures. The Challenge to reclaim Feminism. London: Pluto Press, s. 18-40.

Stenslund, Anette (2009): Nar spillet stemmer lysten. Kandidatspeciale. København: Sociologisk Institut, Københavns Universitet.

Synnevåg, Marit (2002): 128 sider om pornografi. Trondheim: Tapir Akademisk Forlag.

Warner, Michael (1999): The Trouble with Normal. Sex, Politics, and the Ethics of queer Life. Cambridge/Massachusetts: Harvard University Press, s. vii-ix, 1-40. 
Wøldike, Morten Emmerik (2009): Piger bliver ikke lykkelige of analsex. En kritisk undersogelse af seksualmoralske standpunkter. København: SEKSUALITETER (Skriftrække fra Center for Seksualitetsforskning), nr. 2.

Östergren, Petra (2006): Porr, Horor och feminister. Stockholm: Pocketförlaget. 
